\title{
Proposed Improvement of Road Services Quality in Xyz Hospital With Integration of Service Quality (Servqual) Method and Kano Model
}

\author{
Mutmainah $^{1}$, Umi Marfuah ${ }^{2}$, Andreas Tri Panudju ${ }^{3}$ \\ ${ }^{1,2}$ Industrial Engineering Department, Muhammadiyah University of Jakarta, Jakarta, Indonesia \\ ${ }^{3}$ Industrial Engineering Department, Bina Bangsa University, Serang, Indonesia
}

\begin{abstract}
Based on data on patient visits in 2019, it shows that each month the number of patient visits experienced ups and downs in the rate of patient visits, the peak of the decline occurred in June with a reduction of 2491 people $(26 \%$ from the previous month). This shows the dissatisfaction of the service felt by the patient so that there is a problem that makes some patients not come back for treatment at XYZ Hospital.

The method used in this study is the Servqual method and the Kano Model which aim to improve the quality of outpatient services at XYZ Hospital. Based on the results of the collection of Voice of Customer (VOC) which has been translated into 5 Servqual dimensions, namely Tangible, Reliability, Responsiveness, Assurance, and Emphaty obtained 19 service attributes contained on outpatient services at XYZ Hospital.
\end{abstract}

Based on the results of the data processing of the Servqual questionnaire, it is found that the value of the gap (gap) with a positive value of 1 service attribute and 18 service attributes with a negative gap value. By using Importance Performance Analysis (IPA), it is found that 6 service attributes are the main priority for improvement. In data processing with the KANOe model of 18 attributes, it is classified that 6 service attributes are in the Attractive category, 1 service attribute is in the Indifferent category, 7 service attributes are in the Must-be category, and 4 service attributes are in the One-dimensional category. The results of processing with these two methods resulted in a quality improvement proposal with the first priority, namely friendliness and courtesy to patients and families with a gap value of $\mathbf{- 0 . 8 7}$ and the Must-be KANOe category. While the service attribute with the last priority is Ease in the administrative process with a gap value of $\mathbf{- 0 . 8 1}$ and the Attractive KANOe category.

Keyword: Improvement Performance Analysis (IPA), Service Quality, Kano Model, Hospital, Servqual.

\section{INTRODUCTION}

$\mathrm{I}$ $\mathrm{n}$ the current era of globalization, a major influence is felt on the development of science and technology, so that every country must feel the increasingly diverse needs and desires of its people. This is also felt by a large country like Indonesia. Based on the results of the 2015 Inter-Census Population Survey (SUPAS), the population of Indonesia is more than 255 million and is expected to continue to increase. With the large increase in population, it certainly allows big market opportunities for every business actor, one of which is hospitals as a service industry in the health sector. From year to year, the improvement of services and the development of the Hospital is increasingly becoming a public concern. The results of research conducted by the Indonesian Ministry of Health noted that an increase in the number of hospitals each year.

Based on the data, it is explained that there has been an increase in the number of hospitals each year since 2012 with an average of $5.2 \%$. With the average rate of increase in hospitals, competition between hospitals can not be avoided. Every patient expects good facilities as well as friendliness, response, and ability by every worker or nurse in the hospital. Therefore, every hospital is required to provide the best service and be able to meet the level of patient satisfaction as service users and be able to increase the public health index [1].

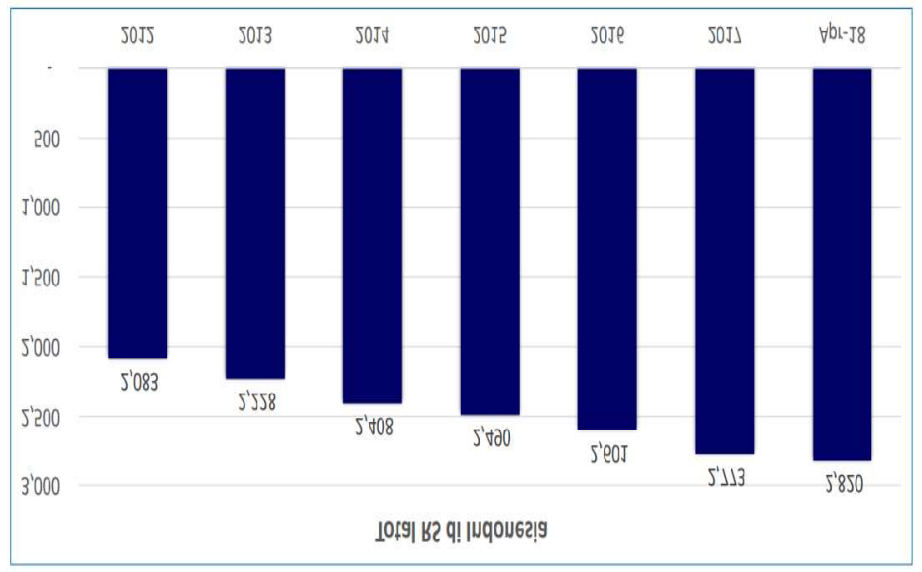

Fig. 1. Graph of Total Hospitals in Indonesia 2012-2018 (Source: KEMKES RI, 2018)

The quality of health services will be very much determined if the needs or expectations of service users are met and received on time [2]. Therefore, health service providers must be able to meet the expectations of service users. In improving the quality of hospital services, customer / patient assessment is needed as a form of service improvement foundation in order to create satisfaction and build loyalty from customers. Customers will provide an assessment of service quality based on how they feel. If other service qualities exist or have been able to understand and provide specific needs of customers and provide better service, it will be possible for customers to 
switch to other service providers [3]. Based on this, each service provider must consider the quality of service in meeting customer satisfaction and carry out management of service quality.

Hospitals as a health service provider are required to provide quality services. In the Law of the Republic of Indonesia No. $36 / 2009$ states that the implementation of health services is carried out in a responsible, safe, high quality, equitable and non-discriminatory manner [4]. Based on the patient's side, patient satisfaction is a level of patient feeling that arises as a result of the health service performance he gets after the patient compares with what he expects. Meanwhile, according to the owner of health service facilities, the view is that quality service is a service that generates revenue that can cover operational and maintenance costs and is in accordance with government standards [5].

Based on the data obtained from the Medical Records section, it can be seen that a decrease occurred in outpatient services at RS XYZ occurred in February 2019 amounting to $798(8 \%)$, in April 2019 amounting to 61 (1\%), in May 2019 amounting to 648 (6\%), in June 2019 it was 2491 (26\%), in August 2019 it was $1536(15 \%)$, in September 2019 it was $763(8 \%)$, and in November 2019 it was 847 (9\%). While the decline that occurred in inpatient services at RS XYZ occurred in April 2019 of $242(17 \%)$, in May 2019 it was $2(0.2 \%)$, in June 2019 it was $129(11 \%)$, in August 2019 it was $119(10 \%)$, and in September $61(6 \%)$. The decrease in visits from these patients shows the dissatisfaction of services felt by patients, so there are problems that make some patients not return for treatment at RS XYZ.

Based on a survey conducted by management in the quality indicator report in 2019, it is known that the average patient satisfaction level is $93 \%$, which means $7 \%$ of patients are dissatisfied with inpatient services at RS XYZ. Meanwhile, the average level of patient satisfaction is $89 \%$, which means $11 \%$ of patients are dissatisfied with outpatient services at RS $\mathrm{XYZ}$, which means that the level of outpatient dissatisfaction is higher than inpatients. This value has exceeded the standard limit of key performance indicators (KPI) for outpatient service units. Therefore, this problem must be resolved immediately by improving outpatient services at RS XYZ. This is what motivates the author to conduct research on outpatient services at RS XYZ in order to improve the quality of outpatient services at RS XYZ.

Outpatient care is one of the services most paid attention to by hospitals because of the very large number of patient visits compared to hospitalizations. Outpatient service facilities provided by RS XYZ include general clinic services, midwifery clinics, pediatric clinics, anesthesia clinics, general surgery clinics, urological surgeries, dental clinics, heart clinics, mental clinics, skin and genital clinics, eye clinics, orthopedic clinics., pulmonary clinic, internal medicine clinic, psychology clinic, medical rehabilitation clinic and physiotherapy, nutrition specialist clinic, neurological clinic, ENT clinic, and radiology clinic.

In this study, the steps taken to improve the quality of outpatient services at RS XYZ is to find out what attributes each patient wants based on the results of observations, interviews, and literature reviews based on Servqual dimensions then a survey is conducted to measure the gap between service perceptions and current service performance, after that categorize service attributes into the Kano method based on the survey results from the types of questions (functional and disfunctional), and then from the results of processing with these two methods will produce priority to improve service attributes.

\section{RESEARCH METHOD}

In this study, the research method used is the Servqual Method [3] to design a questionnaire and determine the gap between expectations and the actual performance of outpatient services at RS XYZ, after that categorize the service attributes into the Kano method based on survey results of the types of questions (functional and dysfunctional) [6], and furthermore, from the results of processing with these two methods will produce priority to increase service attributes.

The population in this study is the number of RS XYZ outpatient service visits in 2019. The sample calculation uses the SLOVIN method [7] to obtain the minimum number that can represent the population as a whole. The Slovin formula is a formula used to calculate the minimum number of samples if the behavior of a population is unknown and not certain.

$n=\frac{N}{\left(1+N e^{2}\right)}$

$n=\frac{113121}{\left(1+\left(113121 \times 0,1^{2}\right)\right.}=99,912=100$

Noted :

$\mathrm{N}=$ Total population

$\mathrm{e}=$ error rate $(10 \%$ or 0.1$)$

$\mathrm{n}=$ Number of Samples

The results of the calculation show that the sample of the research to be carried out is 100 respondents. 


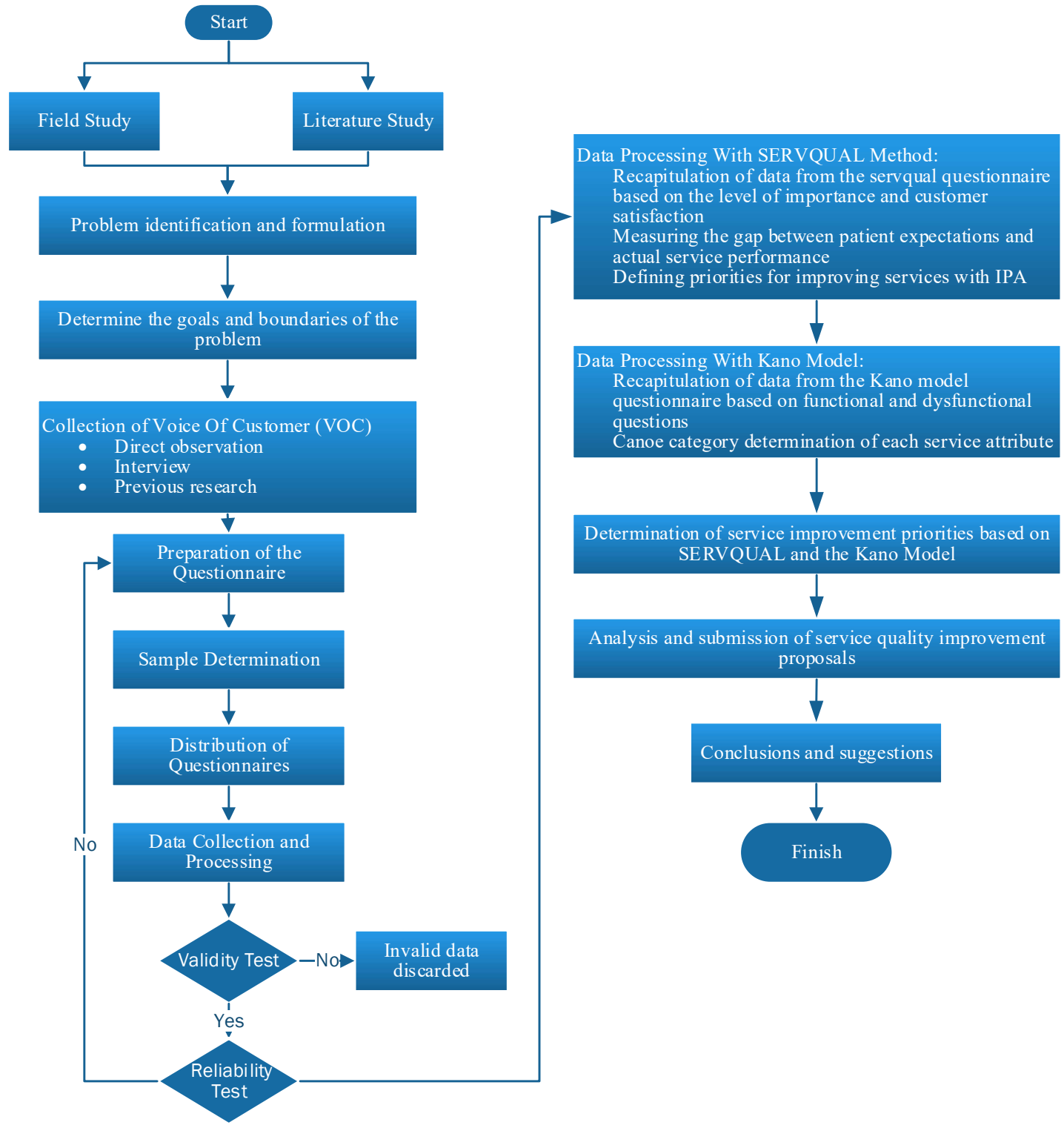

Fig. 2. Research Flowchart

\section{RESULT AND DISCUSSION}

\section{A. Voice Of Customer(VOC) Identification}

Based on the identification of the voice of the customer, there are 19 outpatient service attributes that are identified into five Servqual dimensions. The process of collecting customer voices is carried out by interviewing patients, direct observation, collecting customer complaints, and previous studies or with the same discussion.

Table 1 Service Attributes

\begin{tabular}{|c|c|c|}
\hline No & Service Quality Dimensions & Kode \\
\hline \multicolumn{2}{|c|}{ Tangible } \\
\hline 1 & $\begin{array}{c}\text { Medical personnel and hospital employees are neat and } \\
\text { clean }\end{array}$ & T1 \\
\hline 2 & Cleanliness and comfort of the reception area & T2 \\
\hline
\end{tabular}

\begin{tabular}{|c|c|c|}
\hline 3 & Television facilities or newspapers in the waiting room & $\mathrm{T} 3$ \\
\hline 4 & The availability of sufficient and clean toilets & $\mathrm{T} 4$ \\
\hline \multicolumn{2}{|c|}{ Reliability } \\
\hline 5 & Suitability of service time & $\mathrm{R} 1$ \\
\hline 6 & Ease of administration process & $\mathrm{R} 2$ \\
\hline 7 & Responsiveness & $\mathrm{R} 3$ \\
\hline \multicolumn{3}{|c|}{$\begin{array}{c}\text { The accuracy of the doctor's arrival in providing services } \\
\text { responded to appropriately } \\
\text { understandable clearly and easily }\end{array}$} \\
\hline 8 & RE2 \\
\hline 9 & $\begin{array}{c}\text { Medical personnel convey information } \\
\text { Speed of service time }\end{array}$ & $\mathrm{RE} 3$ \\
\hline 10 & Assurance \\
\hline
\end{tabular}




\begin{tabular}{|c|c|c|}
\hline 11 & Hospital employees have good abilities & A1 \\
\hline 12 & Hospital environment safety & A2 \\
\hline 13 & Hospitality and courtesy to patients and families & A3 \\
\hline 14 & Family atmosphere between medical personnel and patients & A4 \\
\hline 15 & $\begin{array}{c}\text { Medical personnel who are competent in providing health } \\
\text { services }\end{array}$ & A5 \\
\hline \multicolumn{2}{|c|}{ Emphaty } \\
\hline 16 & Doctors provide sufficient service time to patients & E1 \\
\hline 17 & Providing services to patients without being picky (fair) & E2 \\
\hline 18 & $\begin{array}{c}\text { The attention that medical personnel or employees give to } \\
\text { the patient }\end{array}$ & E3 \\
\hline 19 & $\begin{array}{c}\text { Provision of a suggestion box for criticism and suggestions } \\
\text { given batients }\end{array}$ & E4 \\
\hline
\end{tabular}

(Source : Observation Data)

\section{B. Validity Test}

Validity is a data collection tool to measure the ability of an attribute from the data used in research. If the measurement scale is not valid, the data is not useful for researchers because it is not able to measure or represent the whole data. In this study, the validity test was carried out using the Pearson Product Moment method, namely the method used to correlate the results of the scores on each question item with the results of the overall value. The value of $r$ table is obtained from the Product Moment $r$ table (table can be seen in the appendix) using the significance level and the number of samples used. In this study using a significant level of $5 \%$ and a sample size of 100 people, with this value, the $r$ table is 0.1966 . as for the following is the result of the validity test of the level of importance and level of customer satisfaction:

Table 2. Validity Test Table for Customer Satisfaction Levels

\begin{tabular}{|c|c|c|c|}
\hline \multicolumn{4}{|c|}{ Hasil Uji Validitas tingkat harapan palanggan } \\
\hline Kode & Nilai R hitung & Nilai R Tabel & Keterangan \\
\hline T1 & 0,2262 & 0,1946 & Valid \\
\hline T2 & 0,3416 & 0,1946 & Valid \\
\hline T3 & 0,3028 & 0,1946 & Valid \\
\hline T4 & 0,2309 & 0,1946 & Valid \\
\hline R1 & 0,4925 & 0,1946 & Valid \\
\hline R2 & 0,5618 & 0,1946 & Valid \\
\hline R3 & 0,4516 & 0,1946 & Valid \\
\hline RE1 & 0,2498 & 0,1946 & Valid \\
\hline RE2 & 0,2652 & 0,1946 & Valid \\
\hline RE3 & 0,3564 & 0,1946 & Valid \\
\hline A1 & 0,4531 & 0,1946 & Valid \\
\hline A2 & 0,2805 & 0,1946 & Valid \\
\hline A3 & 0,4826 & 0,1946 & Valid \\
\hline A4 & 0,2506 & 0,1946 & Valid \\
\hline A5 & 0,2574 & 0,1946 & Valid \\
\hline E1 & 0,4903 & 0,1946 & Valid \\
\hline E2 & 0,5417 & 0,1946 & Valid \\
\hline E3 & 0,2283 & 0,1946 & Valid \\
\hline E4 & 0,3700 & 0,1946 & Valid \\
\hline
\end{tabular}

(Source: Calculation Result Data)
Table 3. Table of Validity Test of Customer Interest Level

\begin{tabular}{|c|c|c|c|}
\hline Kode & Nilai R hitung & Nilai R Tabel & Keterangan \\
\hline T1 & 0,4741 & 0,1946 & Valid \\
\hline T2 & 0,4128 & 0,1946 & Valid \\
\hline T3 & 0,4288 & 0,1946 & Valid \\
\hline T4 & 0,4301 & 0,1946 & Valid \\
\hline R1 & 0,6015 & 0,1946 & Valid \\
\hline R2 & 0,5347 & 0,1946 & Valid \\
\hline R3 & 0,5360 & 0,1946 & Valid \\
\hline RE1 & 0,2878 & 0,1946 & Valid \\
\hline RE2 & 0,4077 & 0,1946 & Valid \\
\hline RE3 & 0,4545 & 0,1946 & Valid \\
\hline A1 & 0,3439 & 0,1946 & Valid \\
\hline A2 & 0,5837 & 0,1946 & Valid \\
\hline A3 & 0,4272 & 0,1946 & Valid \\
\hline A4 & 0,5675 & 0,1946 & Valid \\
\hline A5 & 0,3590 & 0,1946 & Valid \\
\hline E1 & 0,4402 & 0,1946 & Valid \\
\hline E2 & 0,4465 & 0,1946 & Valid \\
\hline E3 & 0,3966 & 0,1946 & Valid \\
\hline E4 & 0,4028 & 0,1946 & Valid \\
\hline
\end{tabular}

(Source: Calculation Result Data)

Based on the results obtained in the table above, it can be concluded that each service attribute point in the questionnaire is declared valid because $r$ count $\geq r$ table, which means that there are no attribute points on the questionnaire that must be discarded.

\section{Reliability Test}

Reliability test is an activity in measuring the stability and consistency of the respondent in answering matters related to the questions in the questionnaire. Each component of the question can be considered consistent, reliable, and also relevant to use in conducting research if Cronchach's Alpha value is greater than 0.6. The following are the results of the reliability test of the level of importance and the level of customer satisfaction using SPSS Software:

Table 4. Reliability Test Results of Customer Interest Level

\begin{tabular}{|c|c|}
\hline \multicolumn{2}{|c|}{ Reliability Statistics } \\
\hline Cronbach's Alpha & N of Items \\
\hline, 775 & 19 \\
\hline
\end{tabular}

(Source: SPSS Software)

Tabel 5.Reliability Test Results of Customer Satisfaction Levels

\begin{tabular}{|c|c|}
\hline \multicolumn{2}{|c|}{ Reliability Statistics } \\
\hline Cronbach's Alpha & N of Items \\
\hline, 666 & 19 \\
\hline
\end{tabular}

(Source: SPSS Software)

Based on the results of the reliability test using the SPSS software, it can be seen that the Cronchbach's Alpha value is more than 0.6 so that each questionnaire is declared fit for use in research. Based on the results of the calculation, the results of the calculation of each value of importance and satisfaction of the criteria for outpatient services at RS XYZ are obtained. 
Table 6. Value of importance and satisfaction of outpatients at RS XYZ

\begin{tabular}{|c|c|c|c|c|}
\hline $\begin{array}{c}\text { Servqual } \\
\text { Dimension }\end{array}$ & Criteria & Exception & Perception & Gap \\
\hline \multirow{4}{*}{ Tangible } & Medical personnel and hospital employees are neat and clean & 4.07 & 3.68 & -0.39 \\
\hline & Cleanliness and comfort of the reception area & 4.58 & 3.86 & -0.72 \\
\hline & Television facilities or newspapers in the waiting room & 3.56 & 3.66 & 0.10 \\
\hline & The availability of sufficient and clean toilets & 4.30 & 3.84 & -0.46 \\
\hline \multirow{3}{*}{ Reliability } & Suitability of service time & 4.44 & 3.61 & -0.83 \\
\hline & Ease of administration process & 4.45 & 3.58 & -0.87 \\
\hline & The accuracy of the doctor's arrival in providing services & 4.44 & 3.64 & -0.80 \\
\hline \multirow{3}{*}{$\begin{array}{l}\text { Responsivene } \\
\text { ss }\end{array}$} & $\begin{array}{l}\text { Handling of patient problems / complaints can be responded to } \\
\text { appropriately }\end{array}$ & 4.45 & 3.80 & -0.65 \\
\hline & $\begin{array}{c}\text { Medical personnel convey information clearly and easily } \\
\text { understandable }\end{array}$ & 4.79 & 3.83 & -0.96 \\
\hline & Speed of service time & 4.47 & 4.06 & -0.41 \\
\hline \multirow{5}{*}{ Assurance } & Hospital employees have good abilities & 4.49 & 3.68 & -0.81 \\
\hline & Hospital environment safety & 4.47 & 3.94 & -0.53 \\
\hline & Hospitality and courtesy to patients and families & 4.60 & 3.38 & -1.22 \\
\hline & Family atmosphere between medical personnel and patients & 4.19 & 3.67 & -0.52 \\
\hline & Medical personnel who are competent in providing health services & 4.77 & 3.79 & -0.98 \\
\hline \multirow{4}{*}{ Emphaty } & Doctors provide sufficient service time to patients & 4.63 & 3.59 & -1.04 \\
\hline & Providing services to patients without being picky (fair) & 4.20 & 3.60 & -0.60 \\
\hline & The attention that medical personnel or employees give to the patient & 4.63 & 3.73 & -0.90 \\
\hline & $\begin{array}{c}\text { Provision of a suggestion box for criticism and suggestions given by } \\
\text { patients }\end{array}$ & 3.65 & 3.33 & -0.32 \\
\hline
\end{tabular}

(Source: Calculation Result Data)

From the comparison of the level of the gap between the value of interest and patient satisfaction, it can be seen that there are 18 service attributes that have a negative gap value, which means that the service attribute has not met the expectations (expectations) of the patient and 1 service attribute has a gap value. positive, which means that the service attributes have met the expectations (expectations) of the patient. Based on all service attributes there are 4 attributes of the Tangible dimension (Physical Evidence), 3 attributes of the dimension of Reliability (Reliability), 3 attributes of the Responsiveness dimension (Responsiveness), 5 attributes of the Assurance dimension (Assurance), and 4 attributes of the Emphaty dimension (Empathy).

The following is the average of expectations, perceptions, and gap values based on each service dimension based on Servqual:

Table 6. Calculation Results of the Gap (Gap) for each dimension

\begin{tabular}{|c|c|c|c|}
\hline Servqual Dimension & Exception & Perception & Gap \\
\hline Tangible & 4.13 & 3.76 & -0.37 \\
\hline Reliability & 4.44 & 3.61 & -0.83 \\
\hline Responsiveness & 4.57 & 3.90 & -0.67 \\
\hline Assurance & 4.50 & 3.69 & -0.81 \\
\hline Emphaty & 3.42 & 2.85 & -0.57 \\
\hline
\end{tabular}

\begin{tabular}{|c|l|l|l|}
\hline Av. Score & 4.21 & 3.56 & -0.65 \\
\hline
\end{tabular}

(Source: Calculation Results)

Based on the calculation results, the largest gap value is found in the Reliability dimension with a value of -0.83 , for the smallest gap value is in the Tangible dimension with a value of -0.37 , and the average gap value is obtained from each dimension with a value -0.65 . This means that at this time every dimension of service still does not meet patient expectations. Therefore, to analyze the quality of service provided by the management of RS XYZ to patients, the following formula is used:

Quality $(\mathrm{Q})=($ Assessment $(\mathrm{P})) /($ Expectations $(\mathrm{E}))$

With the provision that if the value of Quality $(\mathrm{Q}) \geq 1$, the quality of service provided can be said to be good. Based on the expectations and performance obtained from each service dimension based on Servqual, the quality values for each dimension are obtained as follows:

Table 8. Service Quality for each dimension

\begin{tabular}{|c|c|c|c|}
\hline Servqual Dimension & Exception & Perception & Quality \\
\hline Tangible & 4.13 & 3.76 & 0.91 \\
\hline Reliability & 4.44 & 3.61 & 0.81 \\
\hline Responsiveness & 4.57 & 3.90 & 0.85 \\
\hline
\end{tabular}




\begin{tabular}{|c|l|l|l|}
\hline Assurance & 4.50 & 3.69 & 0.82 \\
\hline Emphaty & 3.42 & 2.85 & 0.83 \\
\hline Av. Score & 4.21 & 3.56 & 0.85 \\
\hline
\end{tabular}

(Source: Calculation Results)

From the results of the calculation of the value of Quality $(\mathrm{Q})$ in the table above, it is obtained an average value of 0.85 , which means the quality of outpatient services provided by RS $\mathrm{XYZ}$ has not been said to be good because the value of Quality (Q) $<1$.

Importance Performance Analysis (IPA)
To define the attributes that are priority for service improvement, it is necessary to analyze Importance Performance Analysis by identifying the average level of interest and patient satisfaction based on the attributes studied which are illustrated by a Cartesian diagram.

Based on the results of data processing using SPSS software, a Cartesian diagram shows the level of satisfaction (performance) of the service attributes described by the $\mathrm{X}$ axis and the level of importance (expectation) of the service attributes described on the $\mathrm{Y}$ axis towards outpatient services at RS XYZ. Here is a Cartesian diagram:

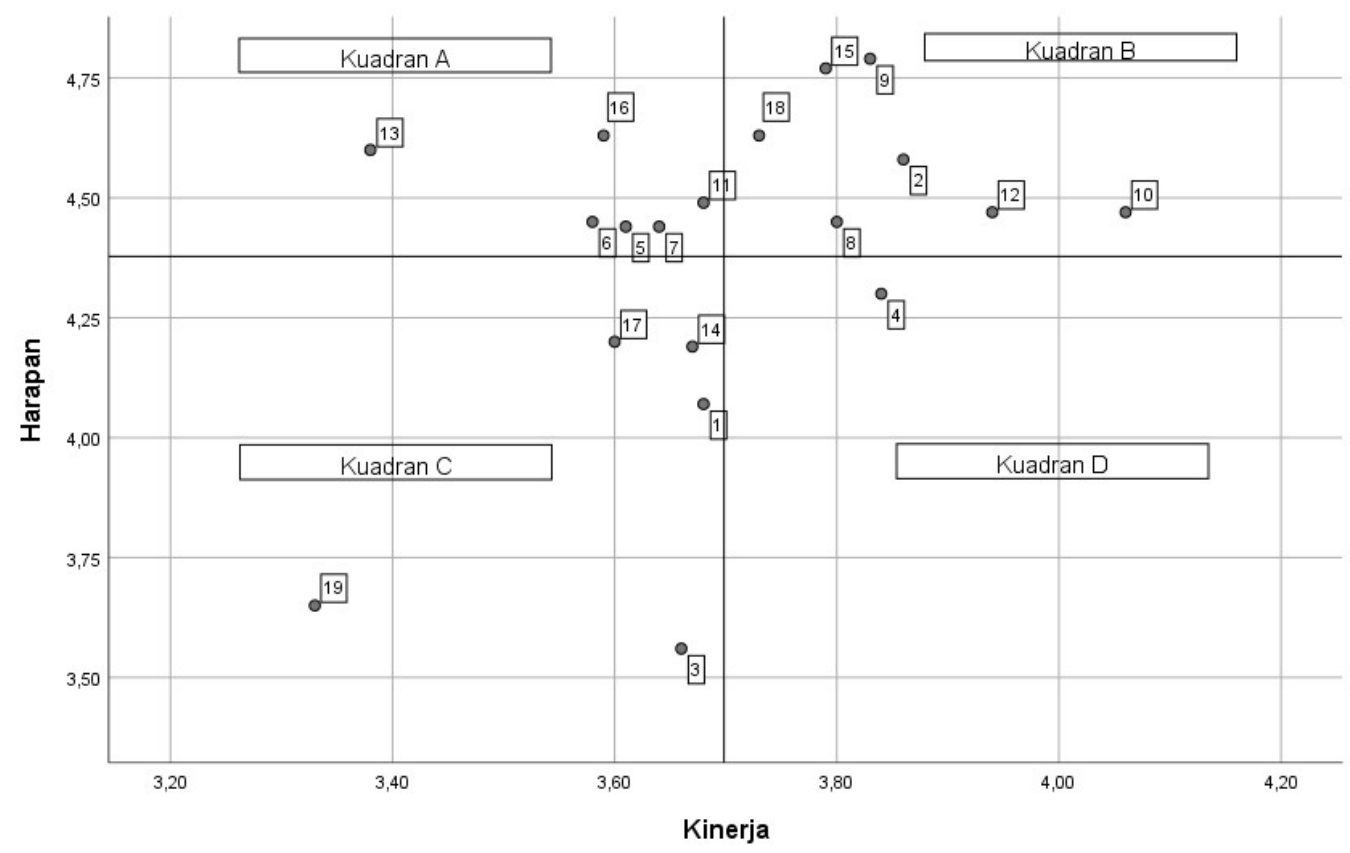

Figure 3. Cartesian diagram

(Source: Data Processing with SPSS)

Based on the results of data processing with SPSS software in Figure 4.6, it can be seen that there are 6 attributes in quadrant A (Main Priority), 7 attributes in quadrant B (Maintain Performance), 5 attributes in quadrant C (Low Priority), and 1 attribute in quadrant D ( Exaggerated). The following is a classification table for Importance Performance Analysis (IPA):

Tabel 9. Importance Performance Analysis (IPA)

\begin{tabular}{|c|c|c|c|c|}
\hline $\begin{array}{c}\text { Servqual } \\
\text { Dimension }\end{array}$ & Criteria & Exception & Perception & Quadrant \\
\hline \multirow{4}{*}{ Tangible } & Medical personnel and hospital employees are neat and clean & 4.07 & 3.68 & $\mathrm{C}$ \\
\cline { 2 - 6 } & Cleanliness and comfort of the reception area & 4.58 & 3.86 & $\mathrm{~B}$ \\
\cline { 2 - 6 } & Television facilities or newspapers in the waiting room & 3.56 & 3.66 & $\mathrm{C}$ \\
\cline { 2 - 6 } & The availability of sufficient and clean toilets & 4.30 & 3.84 & $\mathrm{D}$ \\
\hline \multirow{3}{*}{\begin{tabular}{c} 
Reliability \\
\cline { 2 - 6 }
\end{tabular}} & Suitability of service time & 4.44 & 3.61 & $\mathrm{~A}$ \\
\cline { 2 - 6 } & Ease of administration process & 4.45 & 3.58 & $\mathrm{~A}$ \\
\hline $\begin{array}{c}\text { Responsivenes } \\
\text { s }\end{array}$ & Handling of patient problems / complaints can be responded to \\
appropriately & 4.45 & 3.64 & $\mathrm{~A}$ \\
\hline
\end{tabular}




\begin{tabular}{|c|c|c|c|c|}
\hline & Medical personnel convey information clearly and easily understandable & 4.79 & 3.83 & $\mathrm{~B}$ \\
\hline & Speed of service time & 4.47 & 4.06 & $\mathrm{~B}$ \\
\hline \multirow{5}{*}{ Assurance } & Hospital employees have good abilities & 4.49 & 3.68 & A \\
\hline & Hospital environment safety & 4.47 & 3.94 & $\mathrm{~B}$ \\
\hline & Hospitality and courtesy to patients and families & 4.60 & 3.38 & A \\
\hline & Family atmosphere between medical personnel and patients & 4.19 & 3.67 & $\mathrm{C}$ \\
\hline & Medical personnel who are competent in providing health services & 4.77 & 3.79 & $\mathrm{~B}$ \\
\hline \multirow{4}{*}{ Emphaty } & Doctors provide sufficient service time to patients & 4.63 & 3.59 & A \\
\hline & Providing services to patients without being picky (fair) & 4.20 & 3.60 & $\mathrm{C}$ \\
\hline & The attention that medical personnel or employees give to the patient & 4.63 & 3.73 & $\mathrm{~B}$ \\
\hline & $\begin{array}{l}\text { Provision of a suggestion box for criticism and suggestions given by } \\
\text { patients }\end{array}$ & 3.65 & 3.33 & $\mathrm{C}$ \\
\hline
\end{tabular}

(Source: Calculation Result Data)

\section{Data processing using the Kano Model}

\section{Recapitulation of data from the Kano model questionnaire}

After measuring the level of importance and satisfaction of patients with outpatient services at RS XYZ, the next step is to collect data based on the Kano model by pairing the questionnaire results with Functional (feeling if the attributes are met) and Dysfunctional (feeling if the attributes are not met) of the attributes. outpatient service attributes at RS XYZ based on the KANO classification table. For example, if the respondent on the Functional question (feeling if the attribute is met) gives an answer "Very happy (like)" and on the Dysfunctional question (Feeling if the attribute is not fulfilled) gives an answer "Not happy" then the attribute falls into the One-Dimensional $(\mathrm{O})$ category.

Table 10. Classification of Kano Models

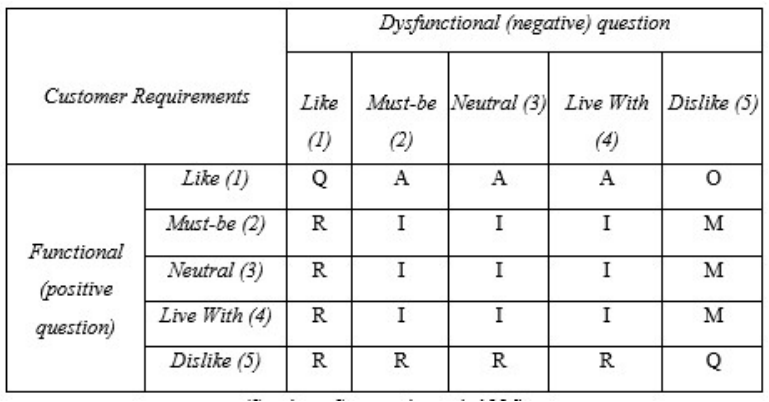

(Sumber : Tan dan Perwira, 2001)
Information :

1. A (Attractive), which is a classification that when it can be fulfilled will have a significant effect on user satisfaction. However, it has no effect on the level of dissatisfaction.(One Dimensional), which is a classification that when met will provide satisfaction to its users linearly (if the service is getting better, the level of satisfaction is so high) and if it is not fulfilled it will give users dissatisfaction.

2. M (Must Be), which is the basic classification that must exist in a product or service standard. If this attribute is not met, it will result in the user being less likely to feel satisfied, whereas if this attribute is met it will only provide a level of satisfaction at a certain level (not significant).

3. I (Indifferent), which is a classification that has no effect on customer satisfaction. Whether the attribute is fulfilled or not does not cause a decrease or increase in the level of satisfaction.

4. R (Reverse), namely the classification of attributes with reverse characteristics, if it is fulfilled, it will give dissatisfaction to the user.

5. Q (Questionable), namely the inaccuracy of customer understanding related to an attribute so that the effect of satisfaction cannot be identified

The following is the frequency of the KANO category based on the results of the questionnaire that has been collected:

Table 11. Frequency of KANO Categories

\begin{tabular}{|c|c|c|c|c|c|c|c|c|}
\hline Code & Service Atributte & A & $\mathrm{O}$ & M & $\mathrm{I}$ & Q & $\mathrm{R}$ & Total \\
\hline $\mathrm{T} 1$ & Medical personnel and hospital employees are neat and clean & 5 & 0 & 52 & 42 & 0 & 1 & 100 \\
\hline $\mathrm{T} 2$ & Cleanliness and comfort of the reception area & 20 & 35 & 22 & 21 & 2 & 0 & 100 \\
\hline $\mathrm{T} 4$ & The availability of sufficient and clean toilets & 5 & 3 & 54 & 37 & 0 & 1 & 100 \\
\hline R1 & Suitability of service time & 28 & 28 & 22 & 22 & 0 & 0 & 100 \\
\hline $\mathrm{R} 2$ & Ease of administration process & 42 & 20 & 17 & 17 & 0 & 4 & 100 \\
\hline R3 & The accuracy of the doctor's arrival in providing services & 48 & 13 & 26 & 12 & 1 & 0 & 100 \\
\hline RE1 & $\begin{array}{c}\begin{array}{c}\text { Handling of patient problems / complaints can be responded to } \\
\text { appropriately }\end{array}\end{array}$ & 30 & 30 & 23 & 16 & 1 & 0 & 100 \\
\hline
\end{tabular}


International Journal of Research and Scientific Innovation (IJRSI) | Volume VIII, Issue I, January 2021 | ISSN 2321-2705

\begin{tabular}{|c|c|c|c|c|c|c|c|c|}
\hline RE2 & Medical personnel convey information clearly and easily understandable & 49 & 6 & 13 & 30 & 2 & 0 & 100 \\
\hline RE3 & Speed of service time & 12 & 1 & 28 & 59 & 0 & 0 & 100 \\
\hline A1 & Hospital employees have good abilities & 6 & 38 & 39 & 15 & 1 & 1 & 100 \\
\hline $\mathrm{A} 2$ & Hospital environment safety & 17 & 39 & 35 & 8 & 0 & 1 & 100 \\
\hline A3 & Hospitality and courtesy to patients and families & 23 & 25 & 26 & 26 & 0 & 0 & 100 \\
\hline A4 & Family atmosphere between medical personnel and patients & 50 & 3 & 2 & 44 & 0 & 1 & 100 \\
\hline A5 & Medical personnel who are competent in providing health services & 7 & 15 & 59 & 18 & 0 & 1 & 100 \\
\hline E1 & Doctors provide sufficient service time to patients & 28 & 23 & 22 & 26 & 0 & 1 & 100 \\
\hline E2 & Providing services to patients without being picky (fair) & 22 & 25 & 35 & 18 & 0 & 0 & 100 \\
\hline E3 & The attention that medical personnel or employees give to the patient & 42 & 9 & 22 & 27 & 0 & 0 & 100 \\
\hline E4 & $\begin{array}{l}\text { Provision of a suggestion box for criticism and suggestions given by } \\
\text { patients }\end{array}$ & 3 & 1 & 59 & 37 & 0 & 0 & 100 \\
\hline
\end{tabular}

(Sumber: Data Hasil Perhitungan)

The data contained in the table above is the result of the recapitulation of the Servqual questionnaire results that have been filled in completely by the respondents with a total of 100 respondents.

\section{Determination of the Kano Category of each service attribute}

After obtaining the Kano category frequency for each service attribute, the next step is to calculate the final determination of the KANO category for each attribute using the Customer Satisfaction (CS) Coefficient which is obtained by first looking for the value of the Customer Satisfaction Index (SI) and the Customer Dissatiscation Index using the following formula:
Satisfaction index $(S I)=\frac{(A+O)}{(A+O+M+I)}$.

Dissatisfaction index $(D I)=\frac{(M+O)}{(A+O+M+I)}$

\section{Information:}

$\mathrm{A}=$ Frequency of the Attractive category of an attribute, $\mathrm{O}=$ Frequency of the One Dimensional category of an attribute, $\mathrm{M}$ $=$ the frequency of the Must Be category of an attribute, and I $=$ the frequency of the Interactive category of an attribute.

The following is the calculation result of each attribute in the Kano Model:

Table 12. Value of the Satisfaction Index and the Dissatisfaction Index

\begin{tabular}{|c|c|c|c|c|c|c|c|c|c|}
\hline Code & Service Atributte & A & $\mathrm{O}$ & M & I & Q & $\mathrm{R}$ & SI Point & $\begin{array}{c}\text { DI } \\
\text { Point }\end{array}$ \\
\hline $\mathrm{T} 1$ & Medical personnel and hospital employees are neat and clean & 5 & 0 & 52 & 42 & 0 & 1 & 0.05 & 0.53 \\
\hline $\mathrm{T} 2$ & Cleanliness and comfort of the reception area & 20 & 35 & 22 & 21 & 2 & 0 & 0.56 & 0.58 \\
\hline $\mathrm{T} 4$ & The availability of sufficient and clean toilets & 5 & 3 & 54 & 37 & 0 & 1 & 0.08 & 0.58 \\
\hline $\mathrm{R} 1$ & Suitability of service time & 28 & 28 & 22 & 22 & 0 & 0 & 0.56 & 0.50 \\
\hline $\mathrm{R} 2$ & Ease of administration process & 42 & 20 & 17 & 17 & 0 & 4 & 0.65 & 0.39 \\
\hline R3 & The accuracy of the doctor's arrival in providing services & 48 & 13 & 26 & 12 & 1 & 0 & 0.62 & 0.39 \\
\hline RE1 & Handling of patient problems / complaints can be responded to appropriately & 30 & 30 & 23 & 16 & 1 & 0 & 0.61 & 0.54 \\
\hline RE2 & Medical personnel convey information clearly and easily understandable & 49 & 6 & 13 & 30 & 2 & 0 & 0.56 & 0.19 \\
\hline RE3 & Speed of service time & 12 & 1 & 28 & 59 & 0 & 0 & 0.13 & 0.29 \\
\hline A1 & Hospital employees have good abilities & 6 & 38 & 39 & 15 & 1 & 1 & 0.45 & 0.79 \\
\hline $\mathrm{A} 2$ & Hospital environment safety & 17 & 39 & 35 & 8 & 0 & 1 & 0.57 & 0.75 \\
\hline A3 & Hospitality and courtesy to patients and families & 23 & 25 & 26 & 26 & 0 & 0 & 0.48 & 0.51 \\
\hline A4 & Family atmosphere between medical personnel and patients & 50 & 3 & 2 & 44 & 0 & 1 & 0.54 & 0.05 \\
\hline A5 & Medical personnel who are competent in providing health services & 7 & 15 & 59 & 18 & 0 & 1 & 0.22 & 0.75 \\
\hline E1 & Doctors provide sufficient service time to patients & 28 & 23 & 22 & 26 & 0 & 1 & 0.52 & 0.45 \\
\hline E2 & Providing services to patients without being picky (fair) & 22 & 25 & 35 & 18 & 0 & 0 & 0.47 & 0.60 \\
\hline E3 & The attention that medical personnel or employees give to the patient & 42 & 9 & 22 & 27 & 0 & 0 & 0.51 & 0.31 \\
\hline E4 & Provision of a suggestion box for criticism and suggestions given by patients & 3 & 1 & 59 & 37 & 0 & 0 & 0.04 & 0.60 \\
\hline
\end{tabular}

(Source: Calculation Result Data) 
Furthermore, the Satisfaction Index (SI) and Dissatisfaction Index (DI) values of each service attribute are described into SI-DI coordinates to classify each service attribute into the Kano category. The SI-DI coordinate values for each KANO category are as follows:

Table 13. SI-DI Coordinate Value for each Kano category

\begin{tabular}{|c|c|c|}
\hline SI Point & DI Point & Kano category \\
\hline$>0.5$ & $<0.5$ & Attractive \\
\hline$>0.5$ & $>0.5$ & One-Dimensional \\
\hline$<0.5$ & $<0.5$ & Indifferent \\
\hline$<0.5$ & $>0.5$ & Must-Be \\
\hline
\end{tabular}

(Source: Coordinate Conversion Results on the SI-DI diagram)

The following are the results of the classification of each service attribute into the KANO model based on the SI-DI value:

Table 14. Results of Kano Classification

\begin{tabular}{|c|c|c|}
\hline $\begin{array}{l}\text { Co } \\
\text { de }\end{array}$ & Service Atributte & $\begin{array}{l}\text { KANO } \\
\text { Category }\end{array}$ \\
\hline $\mathrm{R} 2$ & Ease of administration process & \multirow{6}{*}{ Attractive } \\
\hline R3 & $\begin{array}{l}\text { The accuracy of the doctor's arrival in providing } \\
\text { services }\end{array}$ & \\
\hline $\begin{array}{c}\mathrm{RE} \\
2 \\
\end{array}$ & $\begin{array}{l}\text { Medical personnel convey information clearly and } \\
\text { easily understandable }\end{array}$ & \\
\hline A4 & $\begin{array}{c}\text { Family atmosphere between medical personnel and } \\
\text { patients }\end{array}$ & \\
\hline E1 & Doctors provide sufficient service time to patients & \\
\hline E3 & $\begin{array}{l}\text { The attention that medical personnel or employees } \\
\text { give to the patient }\end{array}$ & \\
\hline $\begin{array}{c}\mathrm{RE} \\
3\end{array}$ & Speed of service time & Indifferent \\
\hline $\mathrm{T} 1$ & $\begin{array}{l}\text { Medical personnel and hospital employees are neat } \\
\text { and clean }\end{array}$ & \multirow{7}{*}{ Must-Be } \\
\hline $\mathrm{T} 4$ & The availability of sufficient and clean toilets & \\
\hline A1 & Hospital employees have good abilities & \\
\hline A3 & Hospitality and courtesy to patients and families & \\
\hline A5 & $\begin{array}{l}\text { Medical personnel who are competent in providing } \\
\text { health services }\end{array}$ & \\
\hline E2 & $\begin{array}{l}\text { Providing services to patients without being picky } \\
\text { (fair) }\end{array}$ & \\
\hline E4 & $\begin{array}{l}\text { Provision of a suggestion box for criticism and } \\
\text { suggestions given by patients }\end{array}$ & \\
\hline $\mathrm{T} 2$ & Cleanliness and comfort of the reception area & \multirow{4}{*}{$\begin{array}{c}\text { One- } \\
\text { Dimensiona } \\
l\end{array}$} \\
\hline R1 & Suitability of service time & \\
\hline $\begin{array}{c}\mathrm{RE} \\
1 \\
\end{array}$ & $\begin{array}{l}\text { Handling of patient problems / complaints can be } \\
\text { responded to appropriately }\end{array}$ & \\
\hline A2 & Hospital environment safety & \\
\hline
\end{tabular}

(Source: Calculation Result Data)

Based on the results of classifying the attributes based on the KANO category, 6 attributes were obtained with the Attractive category, 1 attribute with the Indifferent category, 6 attributes with the Must-be category, and 4 attributes with the One-dimensional category.

\section{Determination of Priority for Service Improvement}

After processing the data using Importance Performance Analysis (IPA) and the KANO Model, the next step is to determine the priority of improving service attributes. Determination of service attributes as the main priority is to choose attributes that are in the Importance Performance Analysis (IPA) in Quadrant A because they have a large level of importance but the current performance according to customers is still lacking (Puspitasari, 2010). Whereas for the KANO category the service attributes that must be improved first are the service attributes with the Must-be category which is the basic category that every service provider must have, after the Must-be category is fulfilled then the service provider must improve performance on the service attributes with the One-Dimensional category., and then the Attractive category as a service attribute that differentiates it from competitors (Walden, 1993). The following are the results of prioritization based on Importance Performance Analysis (IPA) and the KANO Model:

Table 15. Priority for Service Improvement

\begin{tabular}{|c|c|c|c|c|c|}
\hline Code & $\begin{array}{c}\text { Service } \\
\text { Attribute }\end{array}$ & $\begin{array}{c}\text { IPA } \\
\text { Quadrant }\end{array}$ & $\begin{array}{c}\text { KANO } \\
\text { Category }\end{array}$ & GAP & Priority \\
\hline A3 & $\begin{array}{l}\text { Hospitality } \\
\text { and courtesy } \\
\text { to patients } \\
\text { and families }\end{array}$ & A & Must-Be & 0.87 & 1 \\
\hline A1 & $\begin{array}{c}\text { Hospital } \\
\text { employees } \\
\text { have good } \\
\text { abilities }\end{array}$ & A & Must-Be & $\begin{array}{c}- \\
0.83\end{array}$ & 2 \\
\hline R1 & $\begin{array}{l}\text { Suitability of } \\
\text { service time }\end{array}$ & A & $\begin{array}{c}\text { One- } \\
\text { dimensional }\end{array}$ & $\begin{array}{c}- \\
0.80\end{array}$ & 3 \\
\hline R3 & $\begin{array}{l}\text { The accuracy } \\
\text { of the doctor's } \\
\text { arrival in } \\
\text { providing } \\
\text { services }\end{array}$ & A & Attractive & $1 . \overline{2}$ & 4 \\
\hline E1 & $\begin{array}{c}\text { Doctors } \\
\text { provide } \\
\text { sufficient } \\
\text { service time } \\
\text { to patients }\end{array}$ & A & Attractive & 1.04 & 5 \\
\hline $\mathrm{R} 2$ & $\begin{array}{c}\text { Ease of } \\
\text { administration } \\
\text { process }\end{array}$ & A & Attractive & $\begin{array}{c}- \\
0.81\end{array}$ & 6 \\
\hline
\end{tabular}

(Source: Calculation Result Data)

Based on the table above, it is found that there are 6 main priorities for improving outpatient services at RS XYZ with the first order in the service attribute "Hospitality and courtesy to patients and families" and the last priority is the service attribute "Ease in the administrative process".

Fishbone Diagram On Service Attributes That Become Top Priority

After obtaining the service attributes which are the top priority for improving outpatient services at RS XYZ. The next step is to analyze the causes of negative gaps for each attribute using a Cause and Effect Diagram (Fishbone). 


\section{Hospitality and courtesy to patients and families}

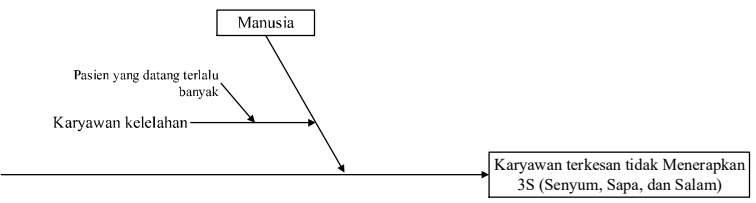

Figure 4.10 Fishbone A3 diagram

Based on the causal diagram (Fishbone), it can be seen the factors that cause gaps in the attribute "Friendliness and courtesy to patients and families". The following are factors that cause the attribute "Friendliness and courtesy to patients and families" to get a negative gap value:

\section{a. Human}

In the human factor, this is because employees are tired because the patients who come every day to receive outpatients are \pm 300 - 400 people.

Based on the analysis of these causes, the authors conducted a brainstorming using $5 \mathrm{~W}+1 \mathrm{H}$ analysis to determine proposed improvements to attributes that had negative gap values. The following is a $5 \mathrm{~W}+1 \mathrm{H}$ table of the attributes "Friendliness and courtesy to patients and families":

Table 16. Analysis of $5 \mathrm{~W}+1 \mathrm{H}$ A3

\begin{tabular}{|c|c|c|c|c|c|c|}
\hline Factor & What & Why & Who & Where & When & How \\
\hline Human & $\begin{array}{c}\text { Exhausted } \\
\text { Employees }\end{array}$ & $\begin{array}{c}\text { Too many } \\
\text { patients are } \\
\text { seeking } \\
\text { treatment }\end{array}$ & $\begin{array}{c}\text { Hospital } \\
\text { employees }\end{array}$ & $\begin{array}{c}\text { Outpatient } \\
\text { Hospital }\end{array}$ & $\begin{array}{c}\text { The entire } \\
\text { outpatient } \\
\text { service process }\end{array}$ & $\begin{array}{c}\text { Consider } \\
\text { increasing the } \\
\text { number of } \\
\text { employees }\end{array}$ \\
\hline
\end{tabular}

(Source: Observation Data)

\section{Hospital employees have good abilities}

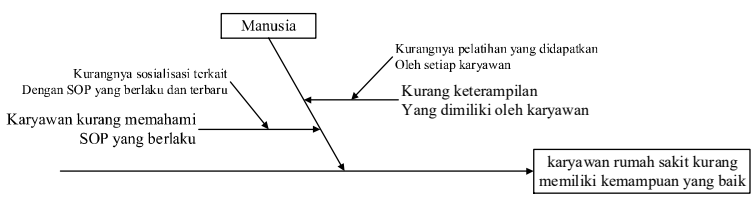

Gambar 4.11 Diagram Fishbone A1

Based on the cause and effect diagram (Fishbone), it can be seen the factors that cause a gap in the attribute "Hospital employees have good abilities". The following are the factors that cause the attribute "Hospital employees have good abilities" to get a negative gap value:

\section{a. Human}

In the human factor, this is because employees do not understand the applicable SOP for outpatient services due to a lack of socialization related to the current and current SOP for outpatient services related to the admission of BPJS patients, which if following the applicable rules the patient will return to receive referrals a week after receiving services. In addition, this is also due to the lack of skills possessed by employees due to the lack of training obtained in accordance with their field of work by each employee, which at this time training is only provided for new employees.

Based on the analysis of these causes, the authors conducted a brainstorming using $5 \mathrm{~W}+1 \mathrm{H}$ analysis to determine proposed improvements to attributes that had negative gap values. The following is a $5 \mathrm{~W}+1 \mathrm{H}$ table of the attributes "Hospital employees have good abilities":

Tabel 17. Analisis $5 \mathrm{~W}+1 \mathrm{H} \mathrm{A} 1$

\begin{tabular}{|c|c|c|c|c|c|c|}
\hline Factor & What & Why & Who & Where & When & How \\
\hline \multirow[t]{2}{*}{ Human } & $\begin{array}{l}\text { Employees do not } \\
\text { understand the } \\
\text { applicable SOP }\end{array}$ & $\begin{array}{l}\text { Lack of SOP } \\
\text { socialization }\end{array}$ & $\begin{array}{l}\text { Hospital } \\
\text { employees }\end{array}$ & $\begin{array}{l}\text { Hospital } \\
\text { outpatient }\end{array}$ & All services & $\begin{array}{c}\text { Socialization is carried out in person } \\
\text { if there is a change in SOP or an } \\
\text { update from the hospital }\end{array}$ \\
\hline & $\begin{array}{c}\text { Lack of employee } \\
\text { skills }\end{array}$ & $\begin{array}{l}\text { Lack of training for } \\
\text { employees }\end{array}$ & $\begin{array}{c}\text { Hospital } \\
\text { employees }\end{array}$ & $\begin{array}{c}\text { Hospital } \\
\text { outpatient }\end{array}$ & All services & Regular training for all employees \\
\hline
\end{tabular}

(Source: Observation Data)

\section{Suitability of service time}

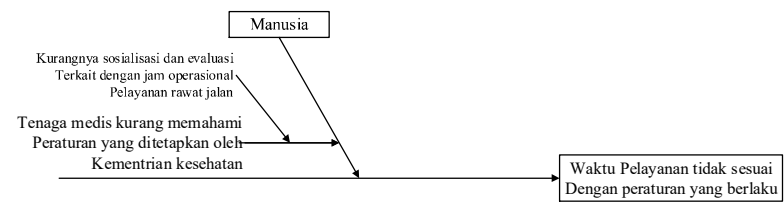

Figure 4.12 Fishbone R1 diagram

Based on the causal diagram (Fishbone), it can be seen the factors that cause gaps in the attribute "Service Time Suitability". The following are the factors that cause the
"Service Time Suitability" attribute to get a negative gap value:

\section{a. Human}

In terms of human factors, this is because medical personnel do not understand the regulations set by the Ministry of Health due to a lack of socialization and evaluation related to the operational hours of outpatient services which should be in PERMENKES No. 129 of 2008, it is explained that the opening hours of outpatient services are from 08.00 to 13.00 every working day except Friday: 08.00 to 11.00 . 
Based on the analysis of these causes, the authors conducted a brainstorming using $5 \mathrm{~W}+1 \mathrm{H}$ analysis to determine proposed improvements to attributes that had negative gap values. The following is a $5 \mathrm{~W}+1 \mathrm{H}$ table of the "Service Time Suitability" attribute:

Tabel 18. 5W+1H R1 Analysis

\begin{tabular}{|c|c|c|c|c|c|c|}
\hline Factor & What & Why & Who & Where & When & How \\
\hline Human & $\begin{array}{c}\text { Medical personnel } \\
\text { do not understand } \\
\text { the regulations set } \\
\text { by the Ministry of } \\
\text { Health }\end{array}$ & $\begin{array}{c}\text { Lack of } \\
\text { socialization and } \\
\text { evaluation related } \\
\text { to the operating } \\
\text { hours of outpatient } \\
\text { services }\end{array}$ & Hospital employees & Hospital outpatient & $\begin{array}{c}\text { All outpatient } \\
\text { services }\end{array}$ & $\begin{array}{l}\text { Socialization related to } \\
\text { operating hours as } \\
\text { determined by the } \\
\text { Ministry of Health }\end{array}$ \\
\hline
\end{tabular}

(Source: Observation Data)

\section{The accuracy of the doctor's arrival in providing services}

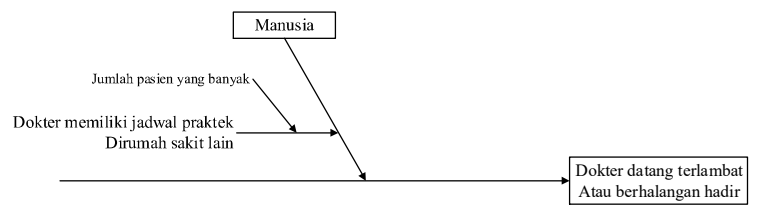

Gambar 4.13 Diagram Fishbone R3

Based on the causal diagram (Fishbone), it can be seen the factors that cause gaps in the attribute "Accuracy of Doctor's Arrival in Providing Services". The following are the factors that cause the attribute "Accuracy of Doctor's Arrival in providing services" to get a negative gap value:

\section{a. Human}

For the human factor, this is because doctors have a practice schedule in another hospital. Based on PERMENKES No.2052 of 2011, every doctor is given a license to practice for three practice places which can be in the same district / city or different in the same province or another province. At XYZ Hospital, doctors who are late or unable to attend are often doctors who work in other hospitals that are different from the province of XYZ Hospital.

Based on the analysis of these causes, the authors conducted a brainstorming using $5 \mathrm{~W}+1 \mathrm{H}$ analysis to determine proposed improvements to attributes that had negative gap values. The following is a $5 \mathrm{~W}+1 \mathrm{H}$ table of the attribute "Accuracy of Doctor's Arrival in providing services":

Tabel 19. 5W+1H R3 Analysis

\begin{tabular}{|c|c|c|c|c|c|c|}
\hline Factor & What & Why & Who & Where & When & How \\
\hline Human & $\begin{array}{c}\text { Doctors have a } \\
\text { schedule at others } \\
\text { hospital }\end{array}$ & $\begin{array}{c}\text { The number of } \\
\text { patients in hospitals } \\
\text { is large }\end{array}$ & $\begin{array}{c}\text { Ophthalmologist and } \\
\text { internal medicine } \\
\text { specialist }\end{array}$ & $\begin{array}{c}\text { Hospital } \\
\text { outpatient }\end{array}$ & Health services & $\begin{array}{c}\text { Consider additional } \\
\text { medical personnel }\end{array}$ \\
\hline
\end{tabular}

(Source: Observation Data)

\section{Doctors provide sufficient service time to patients}

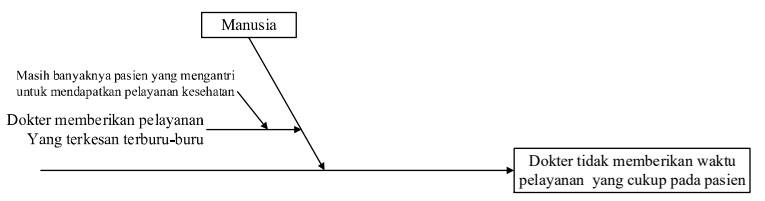

Figure 4.14 Fishbone Diagram E1

Based on the causal diagram (Fishbone), it can be seen the factors that cause a gap in the attribute "Doctors provide sufficient service time to patients". The following are factors that cause the attribute "Doctors provide sufficient service time to patients" to get a negative gap value:

\section{a. Human}

In the human factor, this is because doctors provide services that seem rushed because there are still many patients queuing to get health services. Based on the average examination process to completion takes 10-15 minutes, but with the number of patients in neurological clinics and dental clinics an average of 30-40 patients per day, this certainly requires doctors to provide fast service. Based on the analysis of these causes, the authors conducted a brainstorming using $5 \mathrm{~W}+1 \mathrm{H}$ analysis to determine proposed improvements to attributes that had negative gap values. The following is a $5 \mathrm{~W}+1 \mathrm{H}$ table of the attribute "Doctors provide sufficient service time to patients":

Table 20. Analysis of $5 \mathrm{~W}+1 \mathrm{H} \mathrm{E} 1$

\begin{tabular}{|c|c|c|c|c|c|c|}
\hline Factor & What & Why & Who & Where & When & How \\
\hline Human & $\begin{array}{c}\text { The doctor } \\
\text { provided a rushed } \\
\text { service }\end{array}$ & $\begin{array}{c}\text { There are still many patients } \\
\text { waiting in line to get health } \\
\text { services }\end{array}$ & $\begin{array}{c}\text { Neurologist and dental } \\
\text { specialist }\end{array}$ & $\begin{array}{c}\text { Hospital outpatient } \\
\text { Health } \\
\text { services }\end{array}$ & $\begin{array}{c}\text { Puota of patient visits } \\
\text { at each outpatient } \\
\text { clinic }\end{array}$ \\
\hline
\end{tabular}

(Source: Observation Data) 


\section{Ease in the administrative process}

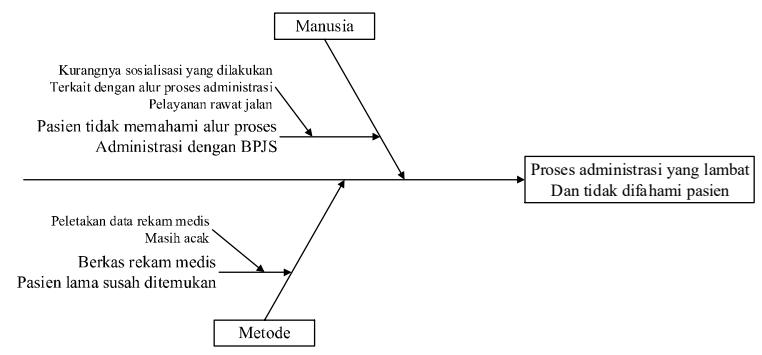

Figure 4.15 Fishbone R2 diagram

Based on the causal diagram (Fishbone), it can be seen the factors that cause gaps in the attribute "Ease in the administrative process". The following are factors that cause the attribute "Ease in the administrative process" to get a negative gap value:

a. Human
In the human factor, this is because the patient does not understand the administrative process, especially for outpatients who use the BPJS due to the lack of socialization carried out by the management regarding the flow of the outpatient service administration process. Based on the statement from the medical records section, the registration process flow is often unknown to new patients with an average number of hospital visits of 150-200 patients per day.

\section{b. Method}

In the method factor, this is because the medical record files of old patients are difficult to find because the placement of medical record data is still random.

Based on the analysis of these causes, the authors conducted a brainstorming using $5 \mathrm{~W}+1 \mathrm{H}$ analysis to determine proposed improvements to attributes that had negative gap values. The following is a $5 \mathrm{~W}+1 \mathrm{H}$ table of the attribute "Ease of administration process":

Table 21. Analysis of 5W + 1H R2

\begin{tabular}{|c|c|c|c|c|c|c|}
\hline Factor & What & Why & Who & Where & When & How \\
\hline Human & $\begin{array}{c}\text { The patient does not } \\
\text { understand the } \\
\text { administration } \\
\text { process }\end{array}$ & $\begin{array}{c}\text { Lack of socialization } \\
\text { related to outpatient } \\
\text { service administration } \\
\text { process flow }\end{array}$ & $\begin{array}{c}\text { Hospital } \\
\text { management }\end{array}$ & $\begin{array}{c}\text { Hospital } \\
\text { outpatient }\end{array}$ & $\begin{array}{c}\text { Administrativ } \\
\text { e Process }\end{array}$ & $\begin{array}{c}\text { Installation of information in the form } \\
\text { of outpatient service process flow }\end{array}$ \\
\hline Method & $\begin{array}{c}\text { The patient's medical } \\
\text { record file is missing }\end{array}$ & $\begin{array}{c}\text { Placement of medical } \\
\text { record data is still random }\end{array}$ & $\begin{array}{c}\text { Hospital } \\
\text { Medical } \\
\text { Records }\end{array}$ & $\begin{array}{c}\text { Hospital } \\
\text { outpatient }\end{array}$ & $\begin{array}{c}\text { Administrativ } \\
\text { e Process }\end{array}$ & $\begin{array}{c}\text { Integration of location and medical } \\
\text { records with information systems }\end{array}$ \\
\hline
\end{tabular}

(Source: Observation Data)

\section{Analysis of Service Quality Assessment Based on Gap Value}

Based on the results of the calculation of the value of the gap in each attribute, it is known that at this time of the 19 service attributes there are 18 attributes with negative gap values that dominate. This indicates that the 18 attributes have not met the patient's expectations. The biggest negative gap value is found in the Assurance dimension, namely in the service attribute "Hospitality and courtesy to patients and families" with a gap value of -1.22 . While the smallest negative gap value is in the Emphaty dimension, namely in the service attribute "Provision of suggestion boxes for criticism and suggestions given by patients".

Cartesian Diagram Analysis on Importance Performance Analysis (IPA)

Data processing using Importance Performance Analysis (IPA) is used to determine and measure the relationship between patient perceptions of current service performance and the necessary service quality improvements. Based on the results of data processing using SPSS software, there are 4 quadrants between Quadrant A (Main Priority), Quadrant B (Maintain Performance), Quadrant C (Low Priority), and Quadrant D (Excessive).

\section{Quadrant A}

The attributes contained in this quadrant are considered important by patients but the service performance in these attributes has not reached the expectations / perceptions of the patient. So that this attribute is a top priority. The following are service attributes that are included in quadrant $\mathrm{A}$ :

a. Suitability of service time

b. Ease of administration process

c. The accuracy of the doctor's arrival in providing services

d. Hospital employees have good abilities

e. Hospitality and courtesy to patients and families

f. Doctors provide sufficient service time to patients

\section{Quadrant B}

The attributes contained in this quadrant are considered important by the patient and the patient considers that service performance in this attribute is considered to have achieved the patient's expectations / perceptions. The following are service attributes that are included in the B quadrant:

a. Cleanliness and comfort of the reception area

b. Handling of patient problems / complaints can be responded to appropriately

c. Medical personnel convey information clearly and easily understandable

d. Speed of service time

e. Hospital environment safety

f. Medical personnel who are competent in providing health services 
g. The attention that medical personnel or employees give to the patient

\section{Quadrant C}

The attributes contained in this quadrant are considered less important by the patient and the service performance in this attribute has not reached the patient's expectations / satisfaction. The following are service attributes that are included in the $\mathrm{C}$ quadrant:

a. Medical personnel and hospital employees are neat and clean

b. Family atmosphere between medical personnel and patients

c. Providing services to patients without being picky (fair)

d. Provision of a suggestion box for criticism and suggestions given by patients

\section{Quadrant D}

The attributes contained in this quadrant are considered insignificant and have not met customer expectations / satisfaction. The following are service attributes that are included in the D quadrant:

\section{a. The availability of sufficient and clean toilets}

Analysis of Service Attribute Classification Using Kano Model Kano processing model is used to classify service attributes based on the influence of service attributes as Functional and Dysfunctional. There are 4 categories of KANO models including the Attractive, Indifferent, One-dimensional, and Must-be categories.

\section{Attractive category}

Attractive category is a KANO model category that becomes an attraction (added value) of a service provider. In this category, if the service attributes are met, it can provide a significant level of customer satisfaction, whereas if it is not met, it will not have a major effect on customer dissatisfaction. The following are service attributes that are classified into the Attractive category:

Tabel 22. Attractive Service Attributes

\begin{tabular}{|c|c|}
\hline Kode & Service Attribute \\
\hline R2 & Ease of administration process \\
\hline R3 & The accuracy of the doctor's arrival in providing services \\
\hline RE2 & $\begin{array}{c}\text { Medical personnel convey information clearly and easily } \\
\text { understandable }\end{array}$ \\
\hline A4 & $\begin{array}{c}\text { Family atmosphere between medical personnel and } \\
\text { patients }\end{array}$ \\
\hline E1 & Doctors provide sufficient service time to patients \\
\hline E3 & $\begin{array}{c}\text { The attention that medical personnel or employees give to } \\
\text { the patient }\end{array}$ \\
\hline
\end{tabular}

(Source: Calculation Result Data)

\section{Indifferent category}

The Indifferent category is a KANO model category that does not really matter to any service user. In this category, whether the service attributes are fulfilled or not fulfilled will not have a major effect on the level of customer satisfaction. The following are service attributes that are classified into the Indifferent category:

Tabel 23. Indifferent Service Attributes

\begin{tabular}{|l|l|}
\hline \multicolumn{1}{|c|}{ Kode } & \multicolumn{1}{c|}{ Service Attribute } \\
\hline RE3 & Speed of service time \\
\hline
\end{tabular}

(Source: Calculation Result Data)

\section{One-dimensional category}

One-dimensional category is a KANO category that has linear (comparable) values. In this category, if the attribute cannot be fulfilled, it will cause customer dissatisfaction and if it is properly fulfilled, it can increase customer satisfaction. The following are service attributes which are classified into Onedimensional categories:

Tabel 24. One-dimensional Atributtes

\begin{tabular}{|l|l|}
\hline Kode & \multicolumn{1}{|c|}{ Service Attribute } \\
\hline T2 & Cleanliness and comfort of the reception area \\
\hline R1 & Suitability of service time \\
\hline RE1 & $\begin{array}{l}\text { Handling of patient problems / complaints can be responded } \\
\text { to appropriately }\end{array}$ \\
\hline A2 & Hospital environment safety \\
\hline
\end{tabular}

(Source: Calculation Result Data)

\section{The Must-be category}

The Must-be category is a KANO model category which is a basic attribute that must be fulfilled by service providers. In the Must-be category, if the service attribute is met, the level of satisfaction felt by the customer increases at a certain point (not significant), whereas if this attribute is not fulfilled, the customer will feel dissatisfied. The following are service attributes that are classified into the Must-be category:

Tabel 25. Must-be Attributes

\begin{tabular}{|c|c|}
\hline Kode & $\begin{array}{c}\text { Service Attribute } \\
\text { T1 }\end{array}$ \\
\hline T4 & $\begin{array}{c}\text { Medical personnel and hospital employees are neat and } \\
\text { clean }\end{array}$ \\
\hline A1 & Hospital employees have good abilities \\
\hline A3 & Hospitality and courtesy to patients and families \\
\hline A5 & $\begin{array}{c}\text { Medical personnel who are competent in providing health } \\
\text { services }\end{array}$ \\
\hline E2 & Providing services to patients without being picky (fair) \\
\hline
\end{tabular}

(Source: Calculation Result Data) 
Analysis of Service Improvement Priorities and Description of Current Conditions

Based on the results of data processing using Importance Performance Analysis (IPA) and the KANO Model, there are 6 service attributes that must be improved, namely:

\section{Hospitality and courtesy to patients and families} (Assurance)

This is related to the friendly attitude and ethical courtesy given by every employee and medical personnel to patients and their families. According to respondents at this time, it was found that both employees or medical personnel were found to be unfriendly to patients and did not apply the $3 \mathrm{~S}$ (smile, greeting, and greeting).

\section{Hospital employees have good abilities (Assurance)}

This relates to the ability of each employee to provide services. According to respondents at this time, in the registration section there were employees who did not understand the insurance patient registration procedure so that patients were doubtful about the abilities possessed by RS XYZ employees.

\section{The suitability of service time (Reliability)}

This is related to the operational time of outpatient services according to the applicable schedule. Some respondents said that currently there are still doctors' practice schedules but they no longer accept patients even though there are still queues.

\section{The accuracy of the doctor's arrival in providing service (Reliability)}

This is related to the punctuality of the doctor's arrival, who is expected to not be late in providing services to patients. The condition that occurs at this time is often found by doctors who are not present on time according to the schedule that has been decided or even suddenly do not come to the hospital. This is often caused by doctors having practice schedules at other hospitals.

\section{Doctors provide sufficient service time to patients (Emphaty)}

This is related to the doctor's attitude who is not in a hurry to provide services so that patients can convey all complaints / problems. According to some respondents at this time there are still doctors who are in a hurry to provide services to patients.

\section{Ease in the administrative process (Reliability)}

This is related to the convenience for each patient to register. At this time, according to some respondents, the administrative process was not well understood by patients and the registration procedure was poorly understood by patients.

Based on the Importance Performance Analysis (IPA) and the KANO Model, the first priority service attributes are friendliness and courtesy to each patient and family who are included in the Assurance dimension with the Must-be category. While the service attribute that becomes the last priority is the kinship atmosphere between medical personnel and patients who are included in the Assurance dimension with the Attractive category.

Analysis of the Causes of Negative Gaps in each of the attributes that are priority improvements

Based on the Cause and Effect Diagram (Fishbone), an analysis of the causes of negative gaps in each attribute is a priority for improving services at RS XYZ as follows:

\section{Hospitality and courtesy to patients and families}

Based on the cause and effect diagram (Fishbone) on this attribute, employees in the registration section seem not to apply 3S (Smiles, Greetings, and Greetings) caused by human factors, namely fatigue felt by employees because patients who come every day to receive outpatient services are $\pm 300-400$ people with the standard registration service time is 5 minutes for each patient while the reality that occurs in the field is 6-7 minutes for each patient.

\section{Hospital employees have good abilities}

Based on the cause and effect diagram (Fishbone) on this attribute, hospital employees do not have good abilities due to human factors, namely employees do not understand the current and latest SOP for outpatient services related to the admission of BPJS patients, which based on applicable regulations patients will receive referrals again. a week after receiving service. In addition, this is also due to the lack of skills possessed by employees due to the lack of training obtained in accordance with their field of work because currently service is only provided for new employees.

\section{Suitability of service time}

Based on the diagram as a result (Fisbone) on this attribute Service time is not in accordance with applicable regulations due to human factors, namely medical personnel do not understand the regulations set by the Ministry of Health due to lack of socialization and evaluation related to operating hours of outpatient services which should be based on regulations which applies to the operational hours of outpatient services from 08.00 to 13.00 every working day except Friday: 09.00 to 11.00 .

\section{The accuracy of the doctor's arrival in providing services}

Based on the cause and effect diagram (Fishbone) on this attribute doctors arrive late or are unable to attend due to human factors, namely doctors have practice schedules at other hospitals and get lots of patients and the distance between other hospitals and XYZ Hospitals of different provinces often causes delays or even the doctor was unable to attend. 


\section{Doctors provide sufficient service time to patients}

Based on the causal diagram (Fishbone) on this attribute doctors do not provide sufficient service time to patients due to human factors, namely doctors are in a hurry to provide health services because there are still many patients waiting in line to get health services. Especially for neurological clinics and dental clinics because the average patient visits per day are $30-40$ people, while the examination process to completion takes 10-15 minutes. This is what requires doctors to provide service quickly.

\section{Ease in the administrative process}

Based on the cause and effect diagram (Fishbone) on this attribute, the administration process is slow and is not understood by the patient due to human factors, namely the patient does not understand the administrative process for BPJS services because of the lack of socialization carried out by management related to the flow of outpatient service administration processes based on the statement section. medical records registration process flow is often unknown to new patients with an average number of visits 150-200 patients per day. In addition, this is also due to method factors, namely the medical record files of old patients are difficult to find because the placement of medical record data is still random and messy.

\section{Proposed Improvement based on $5 \mathrm{~W}+1 \mathrm{H}$ analysis}

Based on the $5 \mathrm{~W}+1 \mathrm{H}$ analysis for each service attribute that is a priority for improvement, the following improvement proposals are obtained:

1. Consider increasing the number of employees

2. Direct socialization if there is a change in Standard Operating Procedures (SOP) and regular training for all employees according to their field of work.

3. Socialization related to operating hours according to regulations set by the Ministry of Health as well as evaluation of the performance given.

4. Consider additional backup medical personnel.

5. Provision of daily quota of patient visits at each outpatient clinic.

6. Installation of information in the form of outpatient service process flow and integration of medical record data locations with information systems.

\section{CONCLUSION}

Based on the results of questionnaire data processing using the Servqual method, it was found that the comparison between the expectation value and the patient's perception at this time there was still a negative value gap, which meant that the patient was not satisfied enough and there were still deficiencies in the quality of outpatient services provided by XYZ Hospital.

Based on determining the priority of service improvement with Cartesian diagrams on Importance Performance Analysis (IPA) and the Kano Model, 6 service attributes are the main priority for improving outpatient services including:

- Suitability of service time

- $\quad$ Ease of administration process

- The accuracy of the doctor's arrival in providing services

- Hospital employees have good abilities

- Hospitality and courtesy to patients and families

- Doctors provide sufficient service time to patients

Based on the service priorities that have been determined using the Servqual method and the Kano model, the proposed improvements obtained through document searches regarding service actions from the XYZ Hospital management are determined.

\section{REFERENCES}

[1] L. Sui Pheng and Z. Rui, "Service Quality for Facilities Management in Hospitals." Springer Singapore, 2016, doi: 10.1007/978-981-10-0956-3.

[2] A. Hussain, E. O. C. Mkpojiogu, and M. N. M. Nawi, "Requirements model for an e-Health awareness portal," 2016, doi: 10.1063/1.4960888.

[3] A. Parasuraman, L. L. Berry, and V. A. Zeithaml, "More on improving service quality measurement," J. Retail., vol. 69, no. 1, pp. 140-147, 1993, doi: 10.1016/s0022-4359(05)80007-7.

[4] L. Listyorini, "Pelayanan Kesehatan Rawat Inap (Studi Tentang Penerapan Peraturan Menteri Kesehatan RI. Nomor 028/ Menkes/ Per/I/2011 Tentang Klinik Di Kabupaten Cilacap),' J. Idea Huk., vol. 1, no. 1, 2015, doi: 10.20884/1.jih.2015.1.1.5.

[5] P. Edastama, "Pengaruh Kualitas Service Terhadap Kepuasan, Kepercayaan, dan Kecenderungan Berperilaku Mahasiswa pada Perguruan Tinggi di Jakarta," J. Manaj. dan Pemasar. Jasa, vol. 7, no. 1, p. 129, 2014, doi: 10.25105/jmpj.v7i1.524.

[6] D. Hilmansyah, "Integrasi Metode Service Quality, Kano Model, dan Quality Function Deployment untuk Peningkatan Kualitas Pelayanan Sekolah Staf dan Komando Angkatan Laut," J. Pertahanan Bela Negara, vol. 6, no. 1, 2016, doi: 10.33172/jpbh.v6i1.301.

[7] Sugiyono, "Rumus Slovin," Journal of Experimental Psychology: General. 2011. 